\title{
THE VALENCE STATES OF 3d: TRANSITION ELEMENTS IN APOLLO 11 AND 12 ROCKS
}

\author{
ALVIN J. COHEN \\ University of Pittsburgh, Pennsylvania, U.S.A.
}

\begin{abstract}
The absorption spectra of Apollo 11 fine-grained rocks, 10017 and 10022 are due entirely to pyroxene minerals. Spectral bands due to $\mathrm{Fe}^{3+}, \mathrm{Fe}^{2+}, \mathrm{Cr}^{3+}$ and $\mathrm{Ti}^{4+}$ and $\mathrm{Ti}^{3+}$ are detected. Single crystals of olivine in rocks 12021 and 12018 show bands due to $\mathrm{Fe}^{3+}, \mathrm{Fe}^{2+}, \mathrm{Cr}^{3+}, \mathrm{Ti}^{3+}, \mathrm{Mn}^{3+}$, and $\mathrm{Mn}^{2+}$. Pyroxenes in the same rocks exhibit band maxima of the same cationic species as in the olivines. Spectral shifts are noted due to anisotrophy of the crystal structures.

Heating sections 10017,10022 , and 12018 from the rock interiors at $200-225^{\circ} \mathrm{C}$ for $2 \mathrm{~h}$ caused large decreases in the spectral intensity of $\mathrm{Fe}^{3+}, \mathrm{Cr}^{3+}$ and $\mathrm{Ti}^{3+}$, indicating the following reaction:

$$
\mathrm{Fe}^{3+}+\mathrm{Cr}^{3+}+\mathrm{Ti}^{3+} \rightarrow \mathrm{Fe}^{2+}+\mathrm{Cr}^{2+}+\mathrm{Ti}^{4+}
$$

This suggests that $\mathrm{Fe}^{3+}, \mathrm{Cr}^{3+}$ and (a portion of) $\mathrm{Ti}^{3+}$ are not in equilibrium. It is most probable that they were produced subsequent to the formation of the rocks by a combination of secondary ionization processes following cosmic ray bombardment and by trace radioactivity present in the rocks.

An orange glass, $150 \mu$ in diam and $50 \mu$ thick contained in brecciated rock, 10048.44, exhibited 15 identifiable absorption bands related to $\mathrm{Fe}^{2+}, \mathrm{Cr}^{3+}, \mathrm{Ti}^{3+}, \mathrm{Mn}^{3+}$ or $\mathrm{Mn}^{2+}$ ions.

Plagioclase in 12021.65 has perfect transmission over the region studied. The limit of $\mathrm{Fe}^{3+}$ is in the order of $<1 \mathrm{ppm}$ and $\mathrm{Fe}^{2+}, 1000 \mathrm{ppm}$ or less in this plagioclase single crystal of dimensions $0.6 \mathrm{~mm} \times$ $0.2 \mathrm{~mm} \times 30 \mu$.
\end{abstract}

\section{Introduction}

Although $\mathrm{Fe}^{3+}$ and $\mathrm{Ti}^{3+}$ have been detected in Apollo 11 rocks by spectrophotometric (Hapke et al., 1960) and by EPR techniques (Weeks et al., 1970), no mechanism for their origin in lunar minerals has hitherto been suggested. The absorption spectra of lunar pyroxene and olivine crystals are reported here in detail for the first time. Due to the random orientation of these crystals, in polished sections $30 \mu$ thick, the anisotropy of the spectra was not investigated.

\section{A. EXPERIMENTAL}

The absorption spectral data were taken using a Cary Model 14 Spectrophotometer with IR-1 Modification and a halogen lamp of variable intensity as a light source in the visible and infrared regions investigated. The spectra of the small single crystals and glass were measured using matched circular slits of $2 \mathrm{~mm}$ diam in sample and reference beams of the instrument. All samples investigated were approximately $30 \mu$ thick except for the orange glass from rock 10048.44 which was approximately $50 \mu$ thick. All single crystals measured were $2 \mathrm{~mm}$ or greater in diameter except the pyroxene, 12018.50 which was a grouping of several smaller crystals. The orange glass was $150 \mu$ in diam, surrounded by an opaque matrix of the breccia in which it was embedded.

The thinness of the specimens studied precluded detection of weak $d$ - $d$ transitions of the $\mathrm{Fe}^{3+}$ ion. The 30 micron thickness was necessary in order to study the intense $\mathrm{Fe}^{3+}$ charge-transfer bands in the ultraviolet region. The $\mathrm{Fe}^{3+}$ band peak could not 


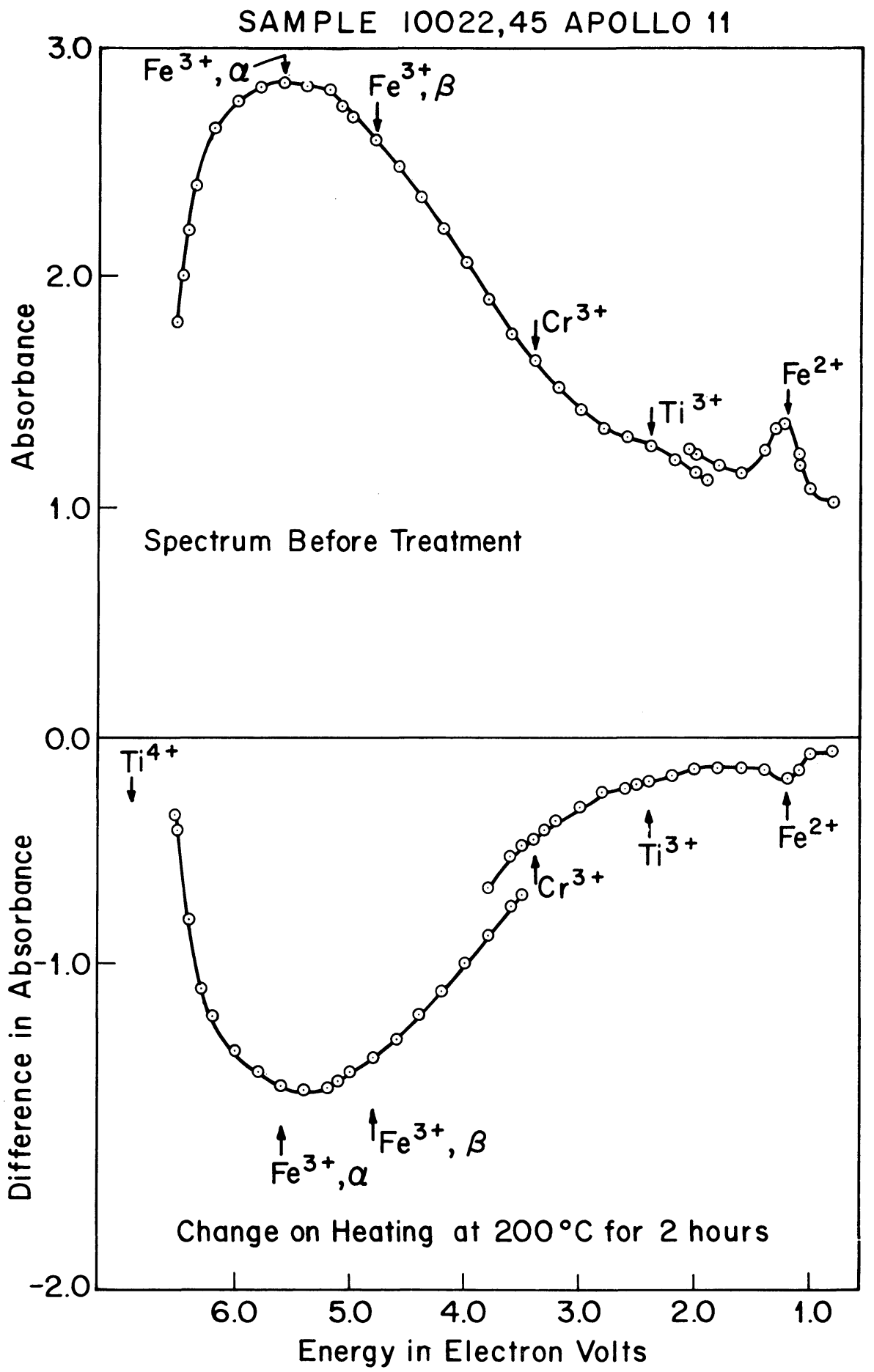

Fig. 1. 
be measured in the orange glass due to the thickness of $50 \mu$. Screens were used in the reference beam to extend the optical density range of the spectrophotometer in order to measure the $\mathrm{Fe}^{3+}$ peak in all cases.

The polished sections were mounted on specially machined brass holders so that the spectrophotometer beam passed only through the sample under investigation, no other extraneous matter being present.

\section{Absorption Spectra of whole Rock Before and after Heating at 200-225 ${ }^{\circ} \mathrm{C}$ for two Hours}

The effect of heating on the absorption spectrum of a polished interior section of Apollo 11 rock, 10017 has been published earlier (Hapke et al., 1970). The heating at $200^{\circ} \mathrm{C}$ for $2 \mathrm{~h}$ followed irradiation with ultraviolet light and X-rays. After standing, the effect is similar to heating pristine 10022 or 12018 pristine interior rock. Figure 1 shows the spectrum of rock 10022.45 before heating and the change in the spectrum caused by heating at $200^{\circ} \mathrm{C}$ for $2 \mathrm{~h}$. The second spectrum is obtained by subtracting the spectrum taken before heating from one measured after heating. The result is a difference spectrum. Spectral bands below zero indicate a decrease in each given band appearing there. This is the result of a decrease in the specific absorbing ion causing the band. Thus one sees in Figure 1 a decrease in bands due to $\mathrm{Fe}^{3+}, \mathrm{Cr}^{3+}$, $\mathrm{Ti}^{3+}$ and $\mathrm{Fe}^{2+}$. Rock 10022 (similarly 10017) contains little olivine but is rich in pyroxenes, plagioclase and ilmenite. The plagioclase is transparent in the region studied and the ilmenite is opaque. The absorption spectrum of this rock is due

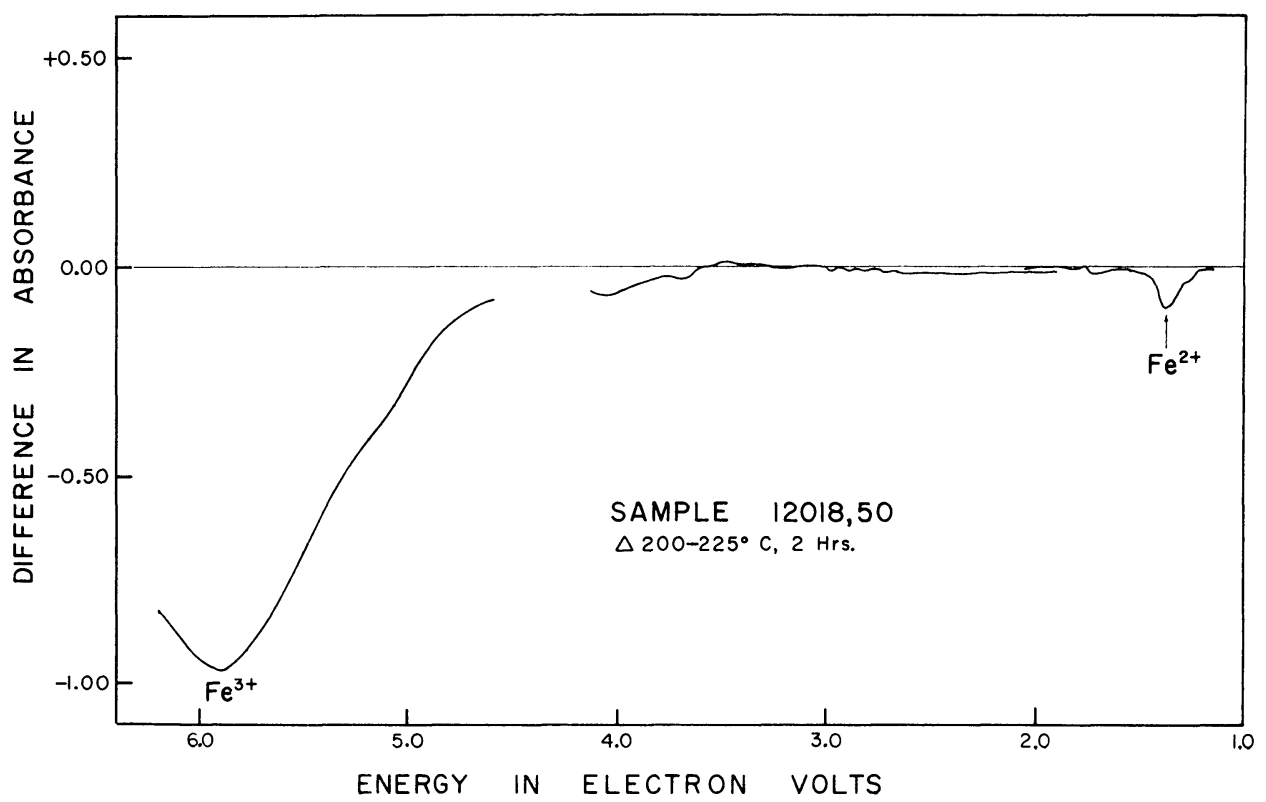

Fig. 2. 
entirely to the pyroxene minerals present and changes upon heating are therefore changes in the pyroxene. The apparent decrease of the $\mathrm{Fe}^{2+}$ on heating is because of the interaction of neighboring $\mathrm{Fe}^{3+}$ and $\mathrm{Fe}^{2+}$, probably across $\mathrm{t} 2 \mathrm{~g}$ orbitals. Thus decrease in the concentration of the $\mathrm{Fe}^{3+}$ causes an apparent decrease in the $\mathrm{Fe}^{2+}$ although the amount of $\mathrm{Fe}^{2+}$ is actually increasing slightly.

Figure 2 illustrates the difference spectrum of Apollo 12 rock 12018.50, an interior portion, upon heating at $200-225^{\circ} \mathrm{C}$ for two hours. The major effects noted are decreases in $\mathrm{Fe}^{3+}$ and $\mathrm{Fe}^{2+}$ bands. This rock contains both pyroxenes and olivine and thus the difference spectrum is more complex than in the other two rocks studied. Table I summarizes the bands found to decrease upon heating at $200-225^{\circ} \mathrm{C}$ in all

TABLE I

Negative difference spectra, after heating at $200-225^{\circ} \mathrm{C}$ for $2 \mathrm{~h}$, all specimens approximately $30 \mu$ thick

\begin{tabular}{llll}
\hline $\begin{array}{l}\text { Absorbing } \\
\text { ion }\end{array}$ & \multicolumn{2}{l}{ Peak maximum in $\mathrm{eV}$} & \\
\cline { 2 - 3 } & $\begin{array}{l}\text { Apollo 11 } \\
10017\end{array}$ & $\begin{array}{l}\text { Apollo 11 } \\
10022\end{array}$ & $\begin{array}{l}\text { Apollo 12 } \\
12018\end{array}$ \\
\hline & & & \\
$\mathrm{Fe}^{2+}$ & 1.1 & 1.3 & $1.28,1.37$ \\
$\mathrm{Ti}^{3+}$ & - & 2.4 & $1.72,2.46$ \\
$\mathrm{Cr}^{3+}$ & $3.2,3.53$ & 3.5 & $1.82,1.94,3.20,3.70,4.06$ \\
$\mathrm{Fe}^{3+}$ & 4.5 & - & - \\
$\mathrm{Cr}^{3+}$ & 4.8 & 4.8 & 5.28 \\
$\mathrm{Fe}^{3+}$ & 5.5 & 5.5 & 5.90 \\
$\mathrm{Ti}^{4+}$ & tail $>6$ & tail $>6$ & tail $>6$ \\
\hline
\end{tabular}

three rocks. The transitions to which the bands are related will be discussed when the spectra of the individual minerals are presented. Two positive bands are observed in Figure 2 at 3.35 and $3.42 \mathrm{eV}$. A band due to $\mathrm{Mn}^{2+}$ appears in spodumene at $3.35 \mathrm{eV}$ (unpublished work) and this may be a similar transition in lunar augite. The band at 3.42 may also be due to $\mathrm{Mn}^{2+}$.

The decrease of $\mathrm{Fe}^{3+}, \mathrm{Cr}^{3+}$ and $\mathrm{Ti}^{3+}$ upon heating at relatively low temperature has been interpreted as reduction of the $\mathrm{Fe}^{3+}$ and $\mathrm{Cr}^{3+}$ accompanied by oxidation of the $\mathrm{Ti}^{3}$ according to the following equation:

$$
\mathrm{Fe}^{3+}+\mathrm{Cr}^{3+}+2 \mathrm{Ti}^{3+} \rightarrow \mathrm{Fe}^{2+}+\mathrm{Cr}^{2+}+2 \mathrm{Ti}^{4+}
$$

This reaction takes place in both pyroxenes and olivine as will be shown later.

An examination of the three rocks studied indicates that they have all cooled slowly. Under these conditions one expects to find the cations in the individual minerals in equilibrium. If this is true, one would not expect oxidation-reduction reactions to take place among the cations at a temperature as low as $200-225^{\circ} \mathrm{C}$. It is known that natural $\alpha$ - and $\beta$-radiation cause oxidation of $\mathrm{Fe}^{2+}$ in terrestrial minerals. $\beta$-radiation is more efficient than $\alpha$-radiation. Cosmic rays are a rich source 
of secondary $\beta$-rays. Therefore it is suggested that both $\mathrm{Fe}^{2+}$ and $\mathrm{Cr}^{2+}$ are oxidized by secondary radiation from cosmic rays as well as by natural radioactivity present in the lunar rocks. $\mathrm{A} \mathrm{Ti}^{4+}$ ion is reduced to $\mathrm{Ti}^{3+}$ for each $\mathrm{Fe}^{2+}$ and $\mathrm{Cr}^{2+}$ originally present in the rock that is oxidized to $\mathrm{Fe}^{3+}$ and $\mathrm{Cr}^{3+}$. It is suggested that a major portion of these three ionic species are produced in the pyroxene and olivine of lunar rocks after the rocks have cooled and been subjected to subsequent radiation.

The conclusion that ferric iron was produced subsequent to the cooling of the rock is strengthened by the low oxygen fugacity found in lunar rocks and by the absence of magnetite.

The probable location of the ions, being oxidized or reduced, in the mineral structure will be suggested when the individual mineral is discussed.

\section{Spectra of Pyroxene in Rocks 12021 and 12018}

Rock 12021 has crystals of large size compared to Apollo 11 rocks. Some pyroxene grains have zones of differing color. These colored zones consist of a core of greenish yellow pigeonite rimmed with a brown zone of augite pyroxene. (Warner, 1970). The absorption spectrum of the pyroxene single-crystal measured in rock 12021.65 was a zoned crystal as described above. The spectrum is shown in Figures 3 and 4 as a dashed curve. The absorption band maxima attributed to $\mathrm{Fe}^{2+}$ are listed in Table II. The $\mathrm{Fe}^{2+}$ spectrum consists of two $d$ - $d$ transitions of $\mathrm{Fe}^{2+}$ in $M_{1}$ sites in the structure and two $d-d$ transitions due to $\mathrm{Fe}^{2+}$ in $M_{2}$ sites. The configuration of the $M_{1}$ site is that of a regular octahedron and that of the $M_{2}$ site is that of a distorted

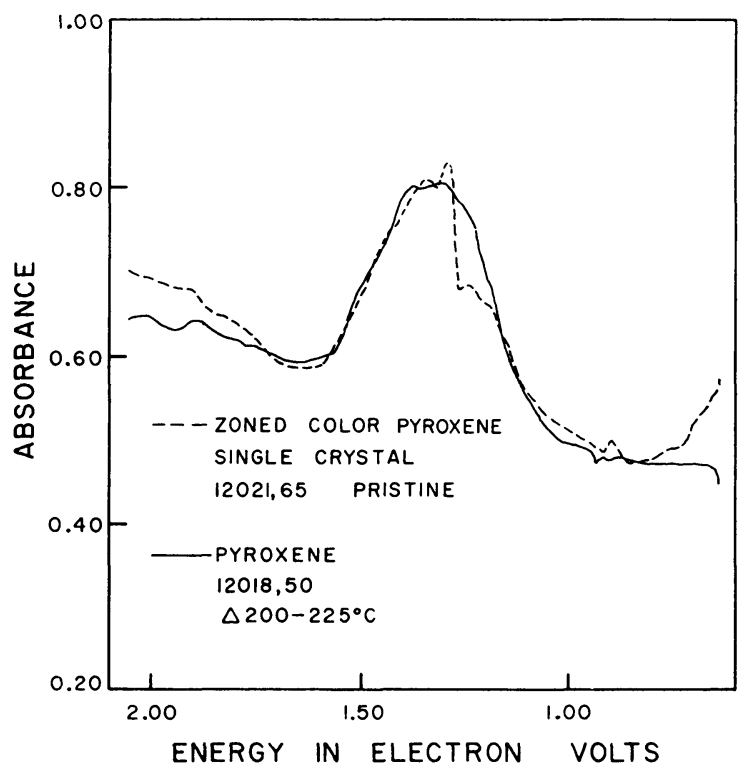

Fig. 3. 


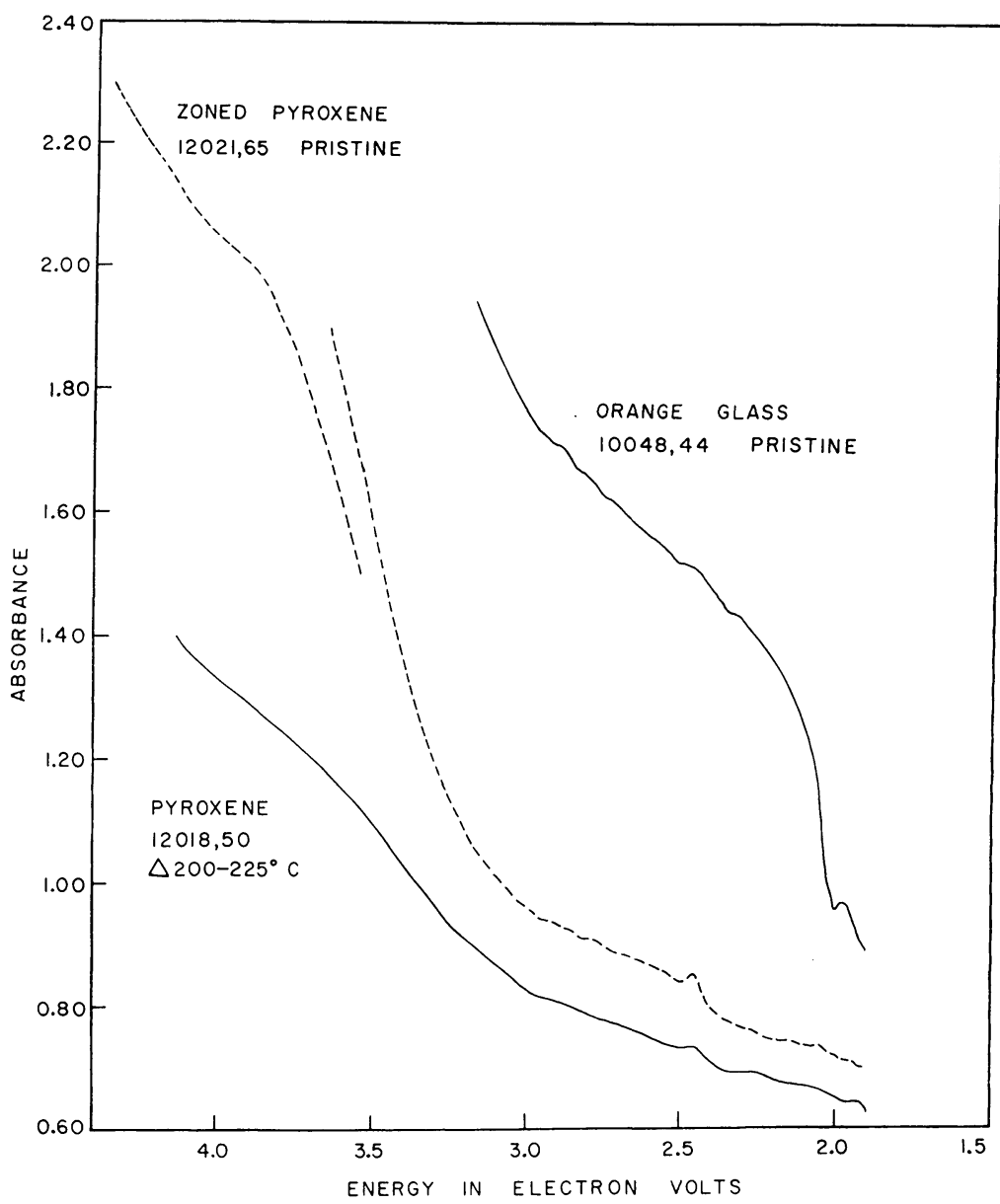

Fig. 4.

TABLE II

Ferrous absorption bands in zoned pyroxene crystal from rock 12021.65

\begin{tabular}{lllr} 
Structural position & $\begin{array}{l}\text { Band maximum } \\
\text { in eV }\end{array}$ & Absorbance & $\Delta \mathrm{cm}^{-1}$ \\
\hline$M_{2}$-pigeonite & 0.675 & 0.58 & \\
$M_{2}$-augite & 0.75 & 0.49 & 5440 \\
$M_{1}$-pigeonite & 1.19 & 0.66 & 6050 \\
$M_{1}$-augite & 1.24 & 0.68 & 9600 \\
$M_{1}$-pigeonite & 1.29 & 0.85 & 10000 \\
$M_{2}$-augite & 1.34 & 0.81 & 10405 \\
$M_{1}$ & 1.41 & 0.76 & 10810 \\
charge transfer Pigeonite & 1.97 & & 11370 \\
$\mathrm{Fe}^{2+} \rightarrow \mathrm{Fe}^{3+}$; Augite & 2.01 & 0.71 & 15890 \\
& & 0.72 & 16210
\end{tabular}


polyhedron. Since one would expect the $\mathrm{Fe}^{2+}$ in an equivalent site in pigeonite to absorb energy at a lower value (longer wavelength) than in titanaugite, the $M_{1}$ and $M_{2}$ absorption bands are doubled (except for the $M_{1}$ transition at $1.41 \mathrm{eV}$ ) for transitions of $\mathrm{Fe}^{2+}$ in each of the two regions of the structurally-zoned pyroxene crystal. The charge-transfer band is also doubled, because of an energy-shift in the two zones of the crystal.

In the pyroxene structure one would ordinarily expect $\mathrm{Fe}^{3+}$ to favor $M_{1}$ positions and $\mathrm{Fe}^{2+}$ to favor $M_{2}$ positions. However, if the $\mathrm{Fe}^{3+}$ is caused by radiation damage it is not yet possible to predict whether a $\mathrm{Fe}^{2+}$ in an $M_{2}$ or $M_{1}$ site will be favored or whether the oxidation of $\mathrm{Fe}^{2+}$ to $\mathrm{Fe}^{3+}$ will be a random process favoring neither structural position.

Table III lists the $\mathrm{Fe}^{2+}$ bands in a wine-brown pyroxene in Apollo 12 rock 12018.50

TABLE III

Ferrous and ferric absorption bands in a poly-crystalline aggregate of pyroxene from rock 12018.50 after heating at $200-225^{\circ} \mathrm{C}$ for $2 \mathrm{~h}$

\begin{tabular}{llllr}
\hline Ion & $\begin{array}{l}\text { Structural } \\
\text { position }\end{array}$ & $\begin{array}{l}\text { Band maximum } \\
\text { in } \mathrm{eV}\end{array}$ & Absorbance & $\Delta \mathrm{cm}^{-1}$ \\
\hline $\mathrm{Fe}^{2+}$ & $M_{2}$ & 0.66 & 0.48 & 5325 \\
$\mathrm{Fe}^{2+}$ & $M_{1}$ & 1.265 & 0.78 & 10205 \\
$\mathrm{Fe}^{2+}$ & $M_{2}$ & 1.31 & 0.80 & 10565 \\
$\mathrm{Fe}^{2+}$ & $M_{1}$ & 1.38 & 0.80 & 11130 \\
$\mathrm{Fe}^{2+}$ & $\begin{array}{l}\text { Charge transfer } \\
\mathrm{Fe}^{3+}\end{array}$ & 1.94 & 0.67 & 15650 \\
& Fe & & & \\
& Charge transfer & 5.635 & 2.54 & 45450
\end{tabular}

after heating at $200-225^{\circ} \mathrm{C}$ for $2 \mathrm{~h}$. The pyroxene crystals in this rock are also relatively large. In the polished section studied, the best region of $2 \mathrm{~mm}$ diam was a clump of pyroxene crystals of the same color. The absorption spectrum of this clump of pyroxene crystals is shown in Figures 3 and 4 . These crystals are of the same thickness as the zoned-crystal in rock 12021. The intensity of the absorption is almost identical in the infra-red region as shown in Figure 3. However, the $\mathrm{Fe}^{2+}$ spectrum is not doubled. In comparing the absorption peak positions to those listed in Table II, one cannot choose whether the polycrystalline aggregate of crystals is pigeonite or augite.

The $\mathrm{Fe}^{3+}$ charge transfer band is so intense in the zoned pyroxene, it could not be measured. In the pyroxene in rock 12018 after heating, the intensity of the $\mathrm{Fe}^{3+}$ band has been reduced enough to be measured as shown in Table III. It is not illustrated but is similar to the $\alpha-\mathrm{Fe}^{3+}$ band in Figure 1 before any heat treatment although of somewhat lower absorbance.

Tables IV and V tabulate the absorption maxima of bands related to manganese that are too weak to be seen readily in the difference spectra of the whole rock; 
TABLE IV

Chromic, titanous, manganic and manganus bands in zoned pyroxene from rock 12021.65

\begin{tabular}{llllll}
\hline Ion & $\begin{array}{l}\text { Probable } \\
\text { structural } \\
\text { position }\end{array}$ & Transition & $\begin{array}{l}\text { Band } \\
\text { maximum } \\
\text { in eV }\end{array}$ & Absorbance & $\Delta \mathrm{cm}^{-1}$ \\
\hline $\mathrm{Cr}^{3+}$ & $M_{1}$ & $d-d$ & & & \\
$\mathrm{Cr}^{3+}$ & $M_{1}$ & $d-d$ & 1.85 & 0.65 & 14920 \\
$\mathrm{Cr}^{3+}$ & $M_{1}$ & Charge transfer & 1.90 & 0.68 & 15325 \\
$\mathrm{Ti}^{3+}$ & $M_{1}$ & Charge transfer & 2.95 & 2.02 & 31860 \\
$\mathrm{Mn}^{3+}$ & $M_{1}$ & $d-d$ & 2.28 & 0.85 & 19760 \\
$\mathrm{Mn}^{2+}$ & $M_{1}$ & $d-d$ & 2.78 & 0.76 & 18390 \\
$\mathrm{Mn}^{2+}$ & $M_{1}$ & $d-d$ & 2.89 & 0.91 & 22425 \\
$\mathrm{Mn}^{2+}$ & $M_{1}$ & $d-d$ & 2.98 & 0.92 & 23310 \\
- & & & & 0.96 & 24035 \\
\hline
\end{tabular}

TABLE V

Chromic, titanous, manganic and manganous bands in pyroxene from rock 12018.50 after heating at $200-225^{\circ} \mathrm{C}$ for $2 \mathrm{~h}$

\begin{tabular}{llllll}
\hline Ion & $\begin{array}{l}\text { Probable } \\
\text { structural } \\
\text { position }\end{array}$ & Transition & $\begin{array}{l}\text { Band } \\
\text { maximum } \\
\text { in eV }\end{array}$ & Absorbance & $\Delta \mathrm{cm}^{-1}$ \\
\hline $\mathrm{Cr}^{3+}$ & $M_{1}$ & $d-d$ & & & \\
& $M_{1}$ & $d-d$ & 1.80 & 0.62 & 14520 \\
& $M_{1}$ & $d-d$ & 1.89 & 0.64 & 15245 \\
& $M_{1}$ & Charge transfer & 2.01 & 0.66 & 16210 \\
$\mathrm{Ti}^{3+}$ & $M_{1}$ & Charge transfer & 3.9 & 0.82 & 23795 \\
& $M_{1}$ & Charge transfer & 1.75 & 1.29 & 31455 \\
$\mathrm{Mn}^{3+}$ & $M_{1}$ & Charge transfer & 2.45 & 0.615 & 14115 \\
$\mathrm{Mn}^{2+}$ & $M_{1}$ & $d-d$ & 0.735 & 19760 \\
$\cdots$ & $M_{1}$ & $d-d$ & 2.28 & 0.68 & 18390 \\
& & & 2.95 & 0.81 & 23795 \\
\hline
\end{tabular}

they are detectable in the spectra of the crystals of pyroxene and olivine. If the major portion of $\mathrm{Fe}^{3+}$ and $\mathrm{Cr}^{3+}$ are produced by oxidation of $\mathrm{Fe}^{2+}$ and $\mathrm{Cr}^{2+}$ respectively then the higher valence states which normally would favor $M_{1}$ positions may be in $M_{2}$ positions. The $\mathrm{Fe}^{3+}\left(3 \mathrm{~d}^{5}\right)$ with zero crystal field stabilization energy would favor the $M_{1}$ site because of its smaller ionic size compared to $\mathrm{Fe}^{2+}$. $\mathrm{The}^{3}{ }^{3+}\left(3 \mathrm{~d}^{5}\right)$ ion would favor the $M_{1}$ sites both for crystal field and ionic size reasons. However $\mathrm{Fe}^{2+}\left(3 \mathrm{~d}^{6}\right)$ and $\mathrm{Cr}^{2+}\left(3 \mathrm{~d}^{4}\right)$ favor $M_{2}$ positions based on site distortion factors. Since the oxidized states are produced after the crystal has formed by radiation damage, one has $\mathrm{Fe}^{3+}$ in a $\mathrm{Fe}^{2+}$ site and $\mathrm{Cr}^{3+}$ in a $\mathrm{Cr}^{2+}$ site. These sites must undergo some local steric readjustment due to the change in cationic charge. The $\mathrm{Ti}^{4+}$ reduced to $\mathrm{Ti}^{3+}$ upon oxidation of the $\mathrm{Fe}^{2+}$ and $\mathrm{Cr}^{3+}$ may be in either silicon sites or $M_{1}$ sites or both, the $M_{1}$ site possibly being favored. 


\section{Spectra of Olivines in Rocks 12021 and 12018}

The olivines in these two Apollo 12 rocks are the largest single crystals present. They are light yellow-green in color in $30 \mu$ thickness. Figure 5 illustrates the $\mathrm{Fe}^{2+}$ spectrum of an olivine crystal in rock 12021.65 as found in the untreated rock and the spectrum of a single olivine crystal in rock 12018.50 after heating at $200-225^{\circ} \mathrm{C}$ for two hours. Tables VI and VII tabulate the $\mathrm{Fe}^{2+}$ band data for these two crystals. The transitions are all $d$ - $d$ except the charge transfer bands near $2.0 \mathrm{eV}$. There is a $\mathrm{Fe}^{3+}$ charge transfer band in the ultraviolet region in the olivine crystal in rock 12021.65 at

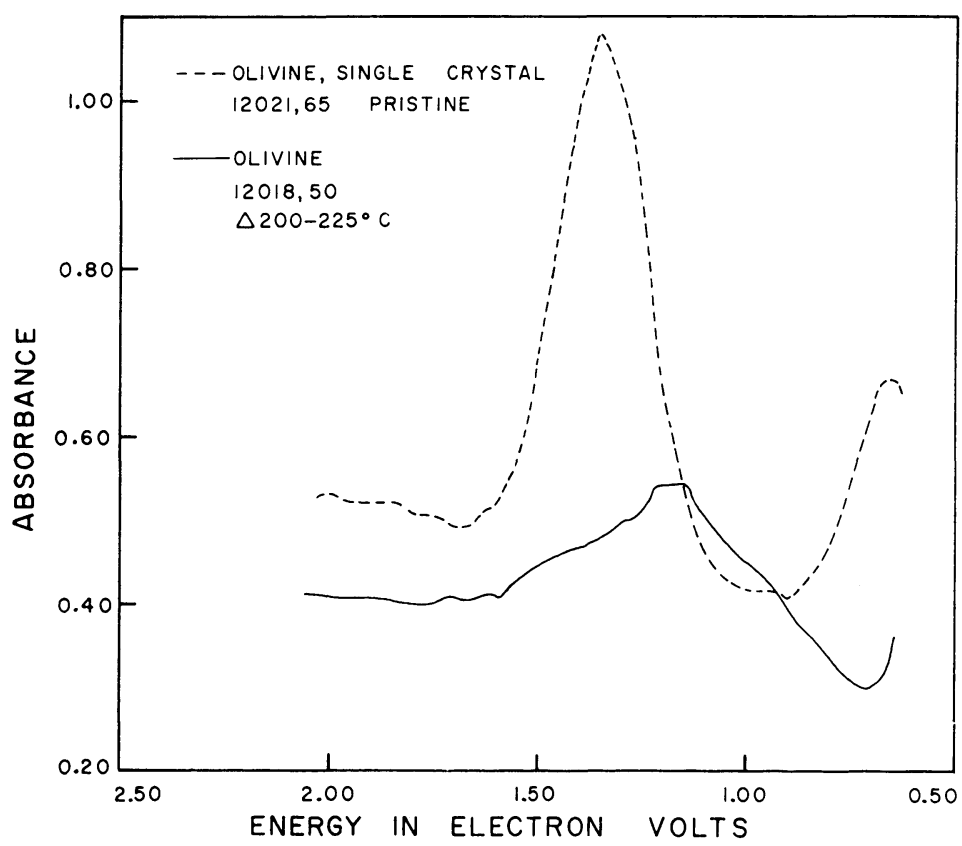

Fig. 5.

TABLE VI

Ferrous absorption band in olivine in rock $\mathbf{1 2 0 2 1 . 6 5}$

\begin{tabular}{lllr}
$\begin{array}{l}\text { Structural } \\
\text { position }\end{array}$ & $\begin{array}{l}\text { Band } \\
\text { maximum } \\
\text { in eV }\end{array}$ & Absorbance & $\Delta \mathrm{cm}^{-1}$ \\
\hline & & & \\
$M_{2}$ & 0.66 & 0.68 & 5325 \\
$M_{1}$ & 1.18 & 0.52 & 9520 \\
$M_{1}$ & 1.34 & 1.08 & 10810 \\
$\mathrm{Charge} \mathrm{transfer}_{\mathrm{Fe}^{2+} \rightarrow \mathrm{Fe}^{3+}}$ & 1.62 & 0.51 & 13065 \\
\hline
\end{tabular}




\section{TABLE VII}

Ferrous absorption bands in olivine in rock 12018.50 after heating at $200-225^{\circ} \mathrm{C}$ for $2 \mathrm{~h}$.

\begin{tabular}{lllr}
$\begin{array}{l}\text { Structural } \\
\text { position }\end{array}$ & $\begin{array}{l}\text { Band } \\
\text { maximum } \\
\text { in } \mathrm{eV}\end{array}$ & Absorbance & $\Delta \mathrm{cm}^{-1}$ \\
& & & \\
$M_{2}$ & 1.18 & 0.54 & 9520 \\
$M_{1}$ & 1.28 & 0.50 & 10325 \\
$M_{1}$ & 1.62 & 0.41 & 13070 \\
Charge transfer & 2.05 & 0.38 & 16535 \\
$\mathrm{Fe}^{2+} \rightarrow \mathrm{Fe}^{3+}$ & & & \\
\hline
\end{tabular}

TABLE VIII

Chromic, titanous, manganic and manganous bands in olivine crystal in rock 12021.65

\begin{tabular}{llllll}
\hline Ion & $\begin{array}{l}\text { Probable } \\
\text { structural } \\
\text { position }\end{array}$ & Transition & $\begin{array}{l}\text { Band } \\
\text { maximum } \\
\text { in eV }\end{array}$ & Absorbance & $\Delta \mathrm{cm}^{-1}$ \\
\hline $\mathrm{Cr}^{3+}$ & $M_{1}$ & $d-d$ & 1.77 & 0.51 & 14275 \\
$\mathrm{Cr}^{3+}$ & $M_{1}$ & $d-d$ & 1.86 & 0.52 & 15000 \\
$\mathrm{Cr}^{3+}$ & $M_{1}$ & Charge transfer & 4.00 & 1.67 & 32265 \\
$\mathrm{Cr}^{3+}$ & & Charge transfer & 4.59 & 2.18 & 37020 \\
$\mathrm{Ti}^{3+}$ & $\mathrm{M}_{1}$ & Charge transfer & 2.44 & 0.645 & 19680 \\
$\mathrm{Mn}^{3+}$ & $M_{1}$ & $\mathrm{Ti}^{3+} \rightarrow \mathrm{Ti}^{4+}$ & & & 18550 \\
$\mathrm{Mn}^{2+}$ & $M_{1}$ & $d-d$ & 2.30 & 0.58 & 21535 \\
\cline { 1 - 2 } & & $d-d$ & 2.67 & 0.67 & \\
\hline
\end{tabular}

TABLE IX

Chromic, Titanous, Manganic and Manganous bands in olive crystal in rock 12018.50 after heating at $200-225^{\circ} \mathrm{C}$ for $2 \mathrm{~h}$

\begin{tabular}{|c|c|c|c|c|c|}
\hline Ion & $\begin{array}{l}\text { Probable } \\
\text { structural } \\
\text { position }\end{array}$ & Transition & $\begin{array}{l}\text { Band } \\
\text { maximum } \\
\text { in } \mathrm{eV}\end{array}$ & Absorbance & $\Delta \mathrm{cm}^{-1}$ \\
\hline $\mathrm{Cr}^{3+}$ & $M_{1}$ & $d-d$ & 1.92 & 0.41 & 15485 \\
\hline $\mathrm{Cr}^{3+}$ & & Charge transfer & 3.24 & 0.55 & 26135 \\
\hline $\mathrm{Cr}^{3+}$ & & Charge transfer & 4.59 & 3.06 & 37020 \\
\hline $\mathrm{Ti}^{3+}$ & $M_{1}$ & Charge transfer & 1.71 & 0.41 & 13790 \\
\hline $\mathrm{Ti}^{3+}$ & $M_{1}$ & $\begin{array}{l}\text { Charge transfer } \\
\mathrm{Ti}^{3+} \rightarrow \mathrm{Ti}^{4+}\end{array}$ & 2.52 & 0.44 & 20325 \\
\hline $\mathrm{Mn}^{3+}$ & $M_{1}$ & $d-d$ & 2.38 & 0.40 & 19195 \\
\hline $\mathrm{Mn}^{2+}$ & $M_{1}$ & $d-d$ & 2.72 & 0.44 & 21940 \\
\hline $\mathrm{Mn}^{2+}$ & $M_{1}$ & $d-d$ & 3.06 & 0.50 & 24680 \\
\hline
\end{tabular}




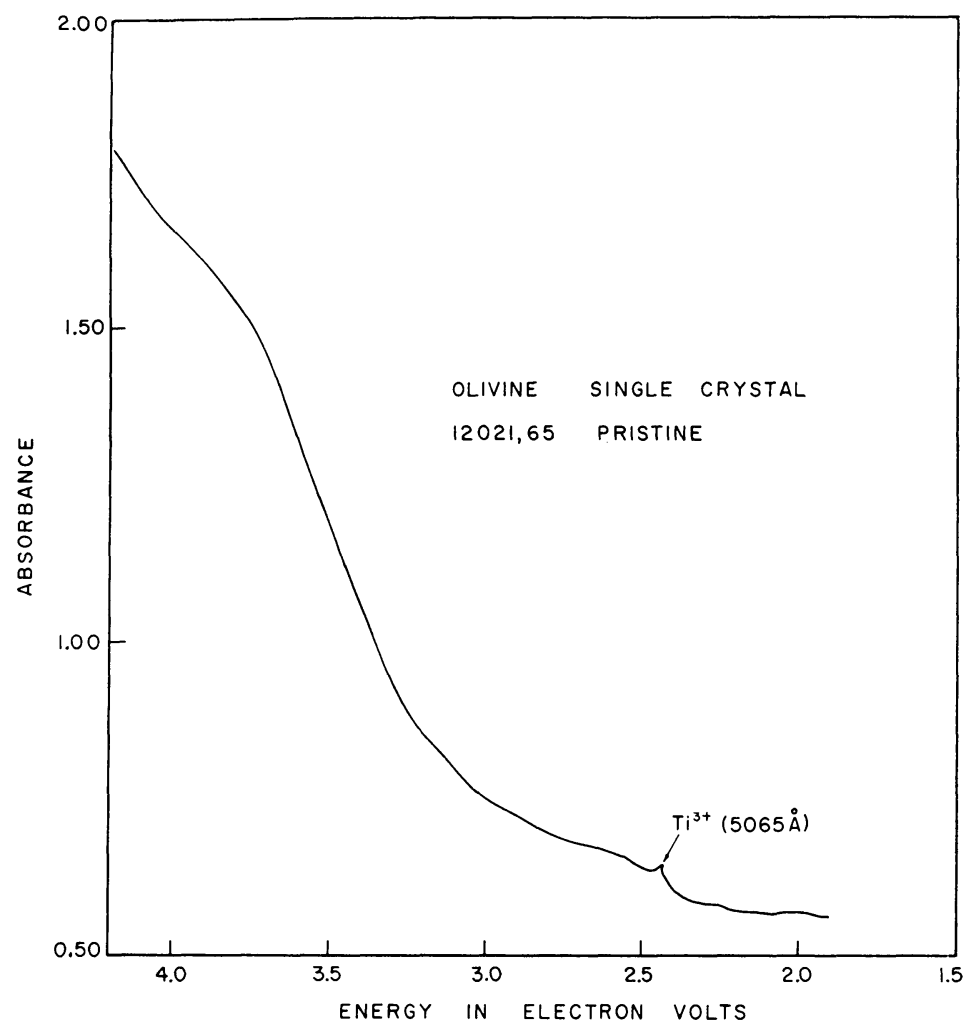

Fig. 6.

$5.64 \mathrm{eV}$ with an absorbance of 2.86. The $\mathrm{Fe}^{3+}$ band was too intense to measure in the heated olivine from rock 12018.50.

The $M_{1}$ structural position in olivine is that of a tetragonally distorted octahedron while the $M_{2}$ site has the configuration of a trigonally distorted octahedron. The $\mathrm{Fe}^{2+}$ ion tends to favor the $M_{2}$ position in olivine.

Tables VIII and IX list the peaks of absorption bands attributed to $\mathrm{Cr}^{3+}, \mathrm{Ti}^{3+}$, $\mathrm{Mn}^{3+}$ and $\mathrm{Mn}^{2+}$ in the two olivines measured.

Figure 6 illustrates the high intensity of the $\mathrm{Cr}^{3+}$ charge-transfer band at $4.00 \mathrm{eV}$ (3100A) compared to the $\mathrm{Ti}^{3+}$ charge transfer band in olivine at $2.44 \mathrm{eV}(5065 \mathrm{~A})$. The $\mathrm{Cr}^{3+}$ band not shown at $4.59 \mathrm{eV}$ is still more intense. This figure indicates that $\mathrm{Cr}^{3+}$ is important in affecting the color on the ultraviolet side of the spectrum as well as $\mathrm{Fe}^{3+}$ in both olivine and pyroxene.

\section{Comparison of Difference Spectrum of Rock 12018.50 to Spectra of Pyroxene and Olivine}

In Table $\mathrm{X}$, the negative peaks in the difference spectrum of rock 12018.50 after heating at $200-225^{\circ} \mathrm{C}$ for $2 \mathrm{~h}$ is compared to the spectra of the individual pyroxene 
TABLE X

Mineral source of difference spectral bands in rock 12018.50

\begin{tabular}{llll}
\hline Ion & $\begin{array}{l}\text { Rock peaks } \\
\text { in } \mathrm{eV} \\
\text { (negative) }\end{array}$ & $\begin{array}{l}\text { Pyroxene } \\
\text { peaks } \\
\text { in } \mathrm{eV}\end{array}$ & $\begin{array}{l}\text { Olivine } \\
\text { peaks } \\
\text { in } \mathrm{eV}\end{array}$ \\
\hline $\mathrm{Fe}$ & & & \\
$\mathrm{Fe}^{2+}$ & 1.28 & 1.31 & 1.28 \\
$\mathrm{Fe}^{2+}$ & 1.37 & 1.38 & 1.41 \\
$\mathrm{Ti}^{3+}$ & 1.72 & 1.75 & 1.71 \\
$\mathrm{Cr}^{3+}$ & 1.82 & 1.80 & - \\
$\mathrm{Cr}^{3+}$ & 1.94 & 1.94 & 1.92 \\
$\mathrm{Ti}^{3+}$ & 2.46 & 2.45 & 2.52 \\
$\mathrm{Mn}^{2+}(?)$ & 2.99 & 2.95 & 3.06 \\
$\mathrm{Cr}^{3+}$ & 3.20 & - & - \\
$\mathrm{Cr}^{3+}$ & 3.70 & - & - \\
$\mathrm{Cr}^{3+}$ & 4.06 & 3.9 & - \\
$\mathrm{Cr}^{3+}$ & 5.28 & - & 4.59 \\
$\mathrm{Fe}^{3+}$ & 5.90 (positive) & 5.64 & - \\
$\mathrm{Mn}^{2+}(?)$ & 3.35 & - & - \\
$\mathrm{Mn}^{2+}(?)$ & 3.42 & - & - \\
\hline
\end{tabular}

and olivine crystals in the same rock after heating. All peaks in the whole rock match peaks of either mineral or both minerals except the charge transfer peaks of $\mathrm{Cr}^{3+}$ (5.28) and $\mathrm{Fe}^{3+}(5.90)$ are shifted to higher energy. Also there is no $\mathrm{Cr}^{3+}$ peak at 3.7 in the minerals. The shift to higher energy in the deep ultraviolet may be apparent rather than real due to the increase of $\mathrm{Ti}^{4+}$ in the vacuum ultraviolet, the tail of which overlaps the $\mathrm{Fe}^{3+}$ and $\mathrm{Cr}^{3+}$ bands in the region 5-6 eV, causing them to appear to be at higher energy. This is caused by the increase in $\mathrm{Ti}^{4+}$ band due to oxidation of the $\mathrm{Ti}^{3+}$ on heating. The entire reaction on heating at $200-225^{\circ} \mathrm{C}$ appears to be:

$$
\mathrm{Fe}^{3+}+\mathrm{Cr}^{3+}+3 \mathrm{Ti}^{3+}\left(+\mathrm{Mn}^{3+}\right) \rightarrow \mathrm{Fe}^{2+}+\mathrm{Cr}^{2+}+3 \mathrm{Ti}^{4+}\left(+\mathrm{Mn}^{2+}\right) .
$$

The data on $\mathrm{Mn}^{2+}$ is uncertain and the positive bands in the difference spectrum of the whole rock at 3.35 and $3.42 \mathrm{eV}$ have not been positively identified.

\section{Spectrum of Plagioclase in Rock 12021.65}

The absorption spectrum of a single crystal of plagioclase in rock 12021.65 with dimensions $0.6 \mathrm{~mm} \times 0.2 \mathrm{~mm}(\times 30 \mu$ thick $)$ was measured. In the wavelength region 2000-17500 $\AA$, there is no light absorption. The absence of the intense $\mathrm{Fe}^{3+}$ charge transfer band in the ultraviolet indicates that the $\mathrm{Fe}^{3+}$ ion in plagioclase is less than one ppm. The weakly absorbing $\mathrm{Fe}^{2+}$ could be present in the order of magnitude of $1000 \mathrm{ppm}$ and not be detected. It is hoped to measure a thicker crystal of lunar plagioclase to see if any spectral bands can be observed. 


\section{The Absorption Spectrum of a Fragment of Oranges Glass in Brecciated Rock 10048.44}

This $150 \mu$ diam particle of orange glass in a polished section of breccia, $50 \mu$ thick had the largest cross-section of any transparent material present. The glass fragment was roughly circular with a bright orange-red color in transmitted light. Figure 4 includes the spectrum of this glass in the visible region, the most prominent band is the $\mathrm{Fe}^{2+} \rightarrow \mathrm{Fe}^{3+}$ charge-transfer band with a maximum at $1.98 \mathrm{eV}$. Figure 7 shows

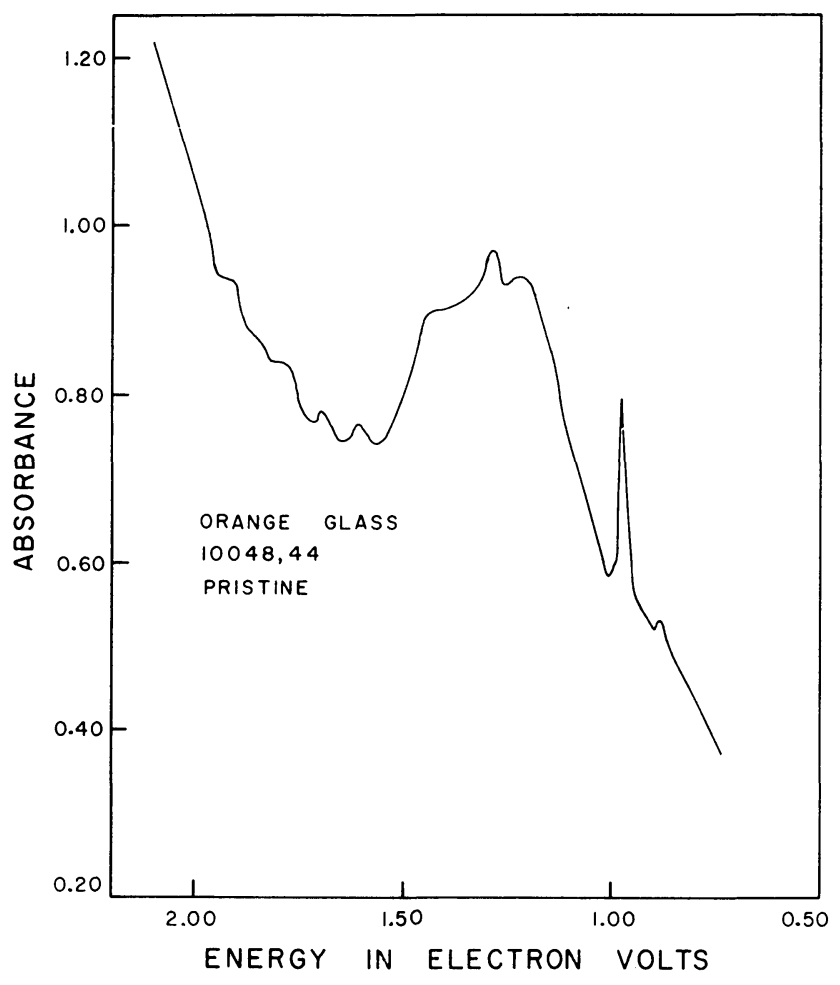

Fig. 7.

the absorption spectrum of the glass in the infra-red region. A prominent vibrational band is present at $0.98 \mathrm{eV}$. The source of this band has not been identified. Table $\mathrm{XI}$ lists the spectral bands present in this glass and the ions responsible. Due to the small size of the fragment, the spectrum could not be observed below $3.18 \mathrm{eV}(3900 \mathrm{~A})$ because of its high intensity of absorption and the small amount of light transmitted by the small size of the fragment. Thus the ferric peak could not be observed although the $1.98 \mathrm{eV} \mathrm{Fe}^{2+} \rightarrow \mathrm{Fe}^{3+}$ charge-transfer band is present indicating that $\mathrm{Fe}^{3+}$ is present in the glass in sufficient quantity to interact with the $\mathrm{Fe}^{2+}$ ion. 
TABLE XI

Absorption bands in orange glass fragment in brecciated rock 10048.44

\begin{tabular}{lllllr} 
Ion & $\begin{array}{l}\text { Probable } \\
\text { configuration }\end{array}$ & Transition & $\begin{array}{l}\text { Band } \\
\text { maximum } \\
\text { in } \mathrm{eV}\end{array}$ & Absorbance & $\Delta \mathrm{cm}^{-1}$ \\
& & & & \\
$\mathrm{Fe}^{2+}$ & octahedral & $d-d$ & 1.22 & 0.94 & 9840 \\
$\mathrm{Fe}^{2+}$ & octahedral & $d-d$ & 1.29 & 0.97 & 10405 \\
$\mathrm{Fe}^{2+}$ & octahedral & $d-d$ & 1.44 & 0.90 & 11615 \\
$\mathrm{Fe}^{2+}$ & octahedral & $d-d$ & 1.61 & 0.77 & 12985 \\
$\mathrm{Fe}^{2+}$ & & Charge transfer & 1.98 & 0.97 & 15970 \\
$\mathrm{Cr}^{3+}$ & octahedral & $d-d$ & 1.80 & 0.84 & 14520 \\
$\mathrm{Cr}^{3+}$ & octahedral & $d-d$ & 1.86 & 0.87 & 15000 \\
$\mathrm{Cr}^{3+}$ & octahedral & $d-d$ & 1.93 & 0.94 & 15565 \\
$\mathrm{Ti}^{3+}$ & octahedral & Charge transfer & 1.69 & 0.78 & 13630 \\
$\mathrm{Ti}^{3+}$ & octahedral & Charge transfer & 2.48 & 1.52 & 20005 \\
$\mathrm{Mn}^{3+}$ & octahedral & $d-d$ & 2.33 & 1.44 & 18795 \\
$\mathrm{Mn}^{2+}$ & octahedral & $d-d$ & 2.18 & 1.33 & 10725 \\
$\mathrm{Mn}^{2+}$ & octahedral & $d-d$ & 2.75 & 1.63 & 22180 \\
$\mathrm{Mn}^{2+}$ & octahedral & $d-d$ & 2.85 & 1.67 & 22985 \\
$\mathrm{Mn}^{2+}$ & octahedral & $d-d$ & 2.91 & 1.71 & 23390 \\
\hline
\end{tabular}

\section{Conclusions}

Heating lunar basaltic rocks at low temperature in air causes reduction of $\mathrm{Fe}^{3+}$ and $\mathrm{Cr}^{3+}$ and oxidation of the $\mathrm{Ti}^{3+}$ in the pyroxenes and olivine present. It is probable that $\mathrm{Mn}^{3+}$ is present and reduced to $\mathrm{Mn}^{2+}$ by the mild heating at 200 to $225^{\circ} \mathrm{C}$. It is suggested that $\mathrm{Fe}^{3+}, \mathrm{Cr}^{3+}$, and $\mathrm{Mn}^{3+}$ are reduced by such a mild heat treatment because they are not in equilibrium in the mineral structure. They are all in sites of the reduced species, viz. a $\mathrm{Fe}^{2+}$ site is the location of $\mathrm{Fe}^{3+}$ in the structure. The structural site must readjust to a smaller cation with different bonding. Electroneutrality is preserved in the crystal by a $\mathrm{Ti}^{3+}$ being oxidized for each cation reduced by radiation. It is suggested that the most likely sources for the oxidation-reduction reactions are $\beta$-rays produced as secondaries following cosmic ray bombardment. Another source of $\beta$ 's is natural radioactivity present in the minerals. Since the rocks studied are from the interior of the rock, the effects of solar X-rays, ultraviolet light, and solar wind protons and electrons are negligible.

Absorption bands of $\mathrm{Cr}^{2+}$ were not detected in any of the specimens studied. Indications of $\mathrm{Ti}^{4+}$ were indicated by increase in the difference spectra of rocks in the deep ultraviolet upon oxidation of the $\mathrm{Ti}^{3+}$ present.

Deep-seated lunar rocks should be lower in $\mathrm{Fe}^{3+}, \mathrm{Cr}^{3+}$, and $\mathrm{Ti}^{3+}$ than surface rocks if the main source of the oxidation-reduction reactions is cosmic ray bombardment. The concentrations of these species should also increase with time of radiation by cosmic rays.

\section{Acknowledgments}

This work was supported by grant NAS 9-9942 of the National Aeronautics and 
Space Administration. Mr Grover Moreland of the National Museum of Natural History, Washington, D.C., is thanked for preparation of the polished sections of lunar rock used in this work. Mr. Ed Skopinski prepared the final drawings of the figures.

Professor S. Keith Runcorn is thanked for the invitation to present this paper at the Moon Symposium at the University of Newcastle upon Tyne.

Note added in Proof: Olivine, single crystal in rocks 12021.65 should read: pigeonite, single crystal in rocks 12021.65 , throughout the text, figures and tables.

\section{References}

Hapke, B. W., Cohen, A. J., Cassidy, W. A., and Wells, E. N.: 1970, 'Solar Radiation Effects on the Optical Properties of Apollo 11 Samples', Proceedings of the Apollo 11 Lunar Science Conference, 3, 2199, Pergamon Press.

Warner, J.: 1970, Apollo 12 Lunar-Sample Information NASA Technical Report R-353, p. 94-96. Weeks, R. A., Kolopus, J. L., Kline D., and Chatelain, A.: 1970, 'Nuclear Resonance of ${ }^{27} \mathrm{Al}$ and Electron resonance of Fe and Mn', Proceedings of the Apollo 11 Lunar Science Conference, 3, 2467, Pergamon Press. 